\title{
Pemanfaatan Pekarangan dengan Pisang Hasil Kultur Jaringan pada Gapoktan Sari Tani di Desa Gentan, Bendosari, Sukoharjo
}

\author{
Samanhudi $^{1,2 *}$, Muji Rahayu ${ }^{1}$, Amalia Tetrani Sakya ${ }^{1}$, Edi Purwanto ${ }^{1}$ \\ ${ }^{1}$ Program Studi Agroteknologi, Fakultas Pertanian, Universitas Sebelas Maret, Surakarta \\ ${ }^{2}$ Pusat Penelitian dan Pengembangan Bioteknologi dan Biodiversitas, LPPM, \\ Universitas Sebelas Maret, Surakarta \\ *Correspoding Author : samanhudi@staff.uns.ac.id
}

\begin{abstract}
ABSTRAK
Pisang merupakan salah satu komoditas buah-buahan yang mudah dibudidayakan di berbagai tempat dan memiliki persyaratan tumbuh relatif mudah. Tanaman pisang sudah banyak diusahakan masyarakat Desa Gentan di pekarangan, namun belum dilakukan perawatan secara intensif sehingga kualitas pisang yang dihasilkan masih rendah. Salah satu penyebabnya yaitu benih yang digunakan diambil dari anakan pisang yang sudah tumbuh sebelumnya, sehingga hasil yang diperoleh juga belum maksimal. Salah satu cara untuk memperbaiki kualitas dan meningkatkan hasil pisang yaitu dengan menanam pisang menggunakan benih hasil perbanyakan secara kultur jaringan. Mitra yang dilibatkan dalam Program Kemitraan Masyarakat ini adalah Gabungan Kelompok Tani Sari Tani yang terdiri atas empat kelompok tani. Kegiatan ini bertujuan untuk memberikan pengenalan, penyuluhan, wawasan, dan informasi budidaya pisang dengan benih hasil kultur jaringan di pekarangan. Tahapan kegiatan diawali dengan koordinasi bersama Gapoktan dan diikuti dengan penyuluhan, praktik lapangan dan pembuatan demplot budidaya pisang, serta monitoring dan evaluasi. Hasil pengabdian kepada masyarakat menunjukkan bahwa penerapan teknologi budidaya tanaman pisang dengan menggunakan benih hasil kultur jaringan dapat diterima dan dilakukan dengan baik oleh anggota Gapoktan Sari Tani. Pemanfaatan pekarangan dengan tanaman pisang menggunakan benih hasil kultur jaringan dilakukan oleh masyarakat setempat dengan sungguhsungguh.
\end{abstract}

Kata kunci: kultur jaringan, pengabdian masyarakat, pisang

\begin{abstract}
Bananas are one of the fruit's commodities that are easy to cultivate in various places and with the requirements of growing relatively easily. Bananas plants have been widely attempted by Gentan villagers in the yard, but have not been carried out intensive cultivation so that the quality of bananas produced is still low. One of the causes is the seeds used are also taken from banana seedlings that have been grown before, so the yield obtained are also not maximal. One way to improve the quality and improve banana yields is to grow bananas using seedlings resulting from tissue culture. The partners involved in the Community Partnership Program are the farmer group unions (Gapoktan) Sari Tani consisting of four farmer groups. This activity aims to provide the introduction, counselling, insight and information of banana cultivation with seeds of tissue culture results in the yard. The stage of the activity began in coordination with Gapoktan and was followed by counselling, field practice and the manufacture of banana cultivation demplot, as well as monitoring and evaluation. The results of community service show that the application of banana cultivation technology using seeds from tissue culture can acceptable and well done by members of Gapoktan Sari Tani. The use of yard with banana plants by using the seeds of tissue culture is carried out by the local community in earnest.
\end{abstract}

Keywords : banana, community services, tissue culture 


\section{PENDAHULUAN}

Pisang merupakan tanaman hortikultura yang memiliki nilai ekonomi tinggi, dapat tumbuh sepanjang tahun dan tidak memerlukan persyaratan tumbuh yang tinggi sehingga mudah untuk dibudidayakan. Buah pisang mengandung berbagai mineral dan vitamin sehingga sangat bermanfaat untuk kesehatan (Ambarita et al., 2016). Pisang merupakan salah satu tanaman buah yang dapat ditanam di pekarangan. Pekarangan merupakan sebidang tanah yang terletak di sekitar rumah dan memiliki batasan tertentu yang dikelilingi dengan pagar dan memiliki hubungan fungsional, ekonomi, biofisik dan sosial budaya dengan penduduknya (Arifin et al., 1996; Nahraeni \& Rahayu, 2015; Sayuti et al., 2019). Pemanfaatan lahan pekarangan di pedesaan dengan mengusahakan tanaman pisang sudah banyak dilakukan. Penerapan teknologi tepat guna dengan menggunakan benih unggul bermutu, akan meningkatkan produksi dan kualitas pisang yang dihasilkan sehingga memenuhi tuntutan kebutuhan pasar secara berkesinambungan (Nahraeni \& Rahayu, 2015).

Petani anggota Gapoktan Sari Tani Desa Gentan sudah biasa melakukan budidaya pisang di pekarangan, namun masih dilakukan secara konvensional. Dalam budidaya pisang, terdapat beberapa permasalahan yang dihadapi oleh masyarakat. Salah satu masalah yang muncul yaitu berkaitan dengan cara yang tepat dalam melakukan perbanyakan benih. Benih pisang sulit untuk didapatkan dalam jumlah yang banyak, memerlukan biaya yang tinggi dan waktu lama dalam persemaian, benih yang tumbuh tidak seragam, serta anakan mudah terserang penyakit. Pada umumnya, benih yang diperoleh berasal dari indukan yang telah ditanam sebelumnya, sehingga jumlahnya terbatas dan kualitasnya beragam.

Untuk meningkatkan kuantitas dan kualitas pisang yang dihasilkan, diperlukan penyediaan benih pisang yang berkualitas. Salah satu cara yang dapat dilakukan untuk menyediakan benih yang bermutu yaitu dengan menggunakan benih pisang hasil perbanyakan secara kultur jaringan. Keuntungan perbanyakan secara kultur jaringan yaitu benih yang dihasilkan bebas hama dan penyakit, mempunyai sifat identik dengan induknya dan dihasilkan benih dalam jumlah yang banyak dalam jangka waktu yang relative singkat serta mudah dalam pengangkutan sehingga biaya menjadi lebih murah (Meynarti, 2010; Suseno, 2017). Selain itu, benih yang dihasilkan dari kultur jaringan bersifat true-to-type, tidak memerlukan tempat yang luas serta dapat diproduksi setiap saat dan sepanjang tahun (Windiastika, 2013; Yusnita, 2004; Jha et al., 2011).

Oleh karena itu, diperlukan informasi mengenai pentingnya penggunaan benih yang berkualitas hasil kultur jaringan dalam budidaya pisang di pekarangan. Hal tersebut dilakukan agar masyarakat anggota Gapoktan Sari Tani mendapatkan pengetahuan dan wawasan, serta mampu meningkatkan kualitas pisang yang dihasilkan dengan menggunakan benih pisang hasil kultur jaringan.

\section{METODE}

\section{Tempat dan Waktu Pengabdian}

Kegiatan pengabdian masyarakat dilakukan kepada Gapoktan Sari Tani, Desa Gentan, Kecamatan Bendosari, Kabupaten Sukoharjo, Jawa Tengah. Penyuluhan dan pengenalan pisang hasil kultur jaringan yang memiliki kualitas lebih tinggi dibandingkan pisang hasil anakan dilaksanakan pada hari Minggu, 28 Juni 2020 (Gambar 1). Kegiatan dilanjutkan dengan pembuatan demplot atau lahan percontohan budidaya tanaman pisang dengan benih hasil kultur jaringan. Pemeliharaan yang dilakukan meliputi penyiraman, pemasangan paranet, pemupukan, serta pengendalian hama penyakit.

\section{Tahapan Pelaksanaan}

\section{Koordinasi dan Observasi}

Koordinasi dilakukan oleh perwakilan tim pengabdian dengan menemui Ketua Gapoktan Sari Tani.

\section{Penyuluhan Perbanyakan Pisang secara Kultur Jaringan dan Budidaya Pisang}

Kegiatan penyuluhan tentang budidaya pisang di pekarangan diikuti sebagian anggota Gapoktan. Beberapa materi yang diberikan antara lain pekarangan dan manfaatanya, produksi benih kultur jaringan, dan budidaya pisang.

\section{Praktik Penanaman}

Kegiatan praktik penanaman dan budidaya pisang hasil kultur jaringan dilakukan secara langsung setelah kegiatan penyuluhan selesai. Demplot budidaya pisang dengan benih hasil 
kultur jaringan dilakukan pada tiga lokasi, dengan menggunakan lahan pekarangan milik anggota Gabungan Kelompok Tani Sari Tani. Pada lahan percontohan/demplot, akan diterapkan teknik budidaya pisang secara intensif meliputi pemberian pupuk secara teratur dan berimbang, pengaturan air, pengendalian hama dan penyakit, serta pemeliharaan rutin lainnya.

\section{Monitoring dan Evaluasi}

Kegiatan monitoring evaluasi dilakukan secara berkala sebagai upaya pembinaan dan pendampingan mitra sampai berhasil menerapkan teknologi budidaya tanaman pisang. Selain itu, anggota Gapoktan dapat juga berkonsultasi budidaya pisang setiap saat.

\section{HASIL DAN PEMBAHASAN}

\section{Koordinasi dan Observasi}

Kegiatan pengabdian masyarakat ini diawali dengan koordinasi antara tim pengabdian masyarakat dengan mitra di rumah Ketua Gapoktan Sari Tani. Koordinasi dilakukan untuk menyamakan persepsi berkaitan dengan kegiatan yang akan dilaksanakan serta membuat agenda pelaksanaan kegiatan. Selanjutnya, dilakukan observasi kondisi lingkungan Desa Gentan dan penentuan lahan pekarangan yang digunakan sebagai lahan percontohan. Dalam koordinasi ini disepakati bahwa kegiatan penyuluhan dan pengenalan budidaya pisang menggunakan benih hasil kultur jaringan akan dilaksanakan pada hari Minggu, 28 Juni 2020.

\section{Penyuluhan Perbanyakan Pisang secara Kultur Jaringan dan Budidaya Pisang}

Peserta yang mengikuti penyuluhan sebanyak 35 orang yang berasal dari perwakilan empat kelompok tani anggota Gapoktan Sari Tani yaitu Kelompok Tani Sumber Winih, Kelompok Tani Sumber Agung, Kelompok Tani Trampil Kasil, dan Kelompok Tani Siti Aji. Penyuluhan tidak dapat diikuti oleh semua anggota Gapoktan karena masih dalam suasana pandemi, sehingga dilakukan pembatasan jumlah peserta. Penyuluhan dibuka oleh Kepala Desa Gentan, Drs. Sudadiyo (Gambar 1).

Meskipun peserta penyuluhan dibatasi hanya perwakilan masing-masing kelompok tani, peserta sangat berminat dan tertarik mengikuti penyuluhan. Hal ini terlihat dengan banyaknya pertanyaan mengenai pembuatan benih pisang secara kultur jaringan dan budidaya pisang yang tepat. Materi penyuluhan yang diberikan meliputi bagaimana cara produksi atau menghasilkan benih melalui kultur jaringan serta cara budidaya tanaman pisang hasil kultur jaringan yang baik. Melalui kegiatan ini, diharapkan petani mempunyai tambahan wawasan dan pengetahuan berkaitan dengan budidaya pisang sehingga akan dapat memberikan hasil yang optimal.

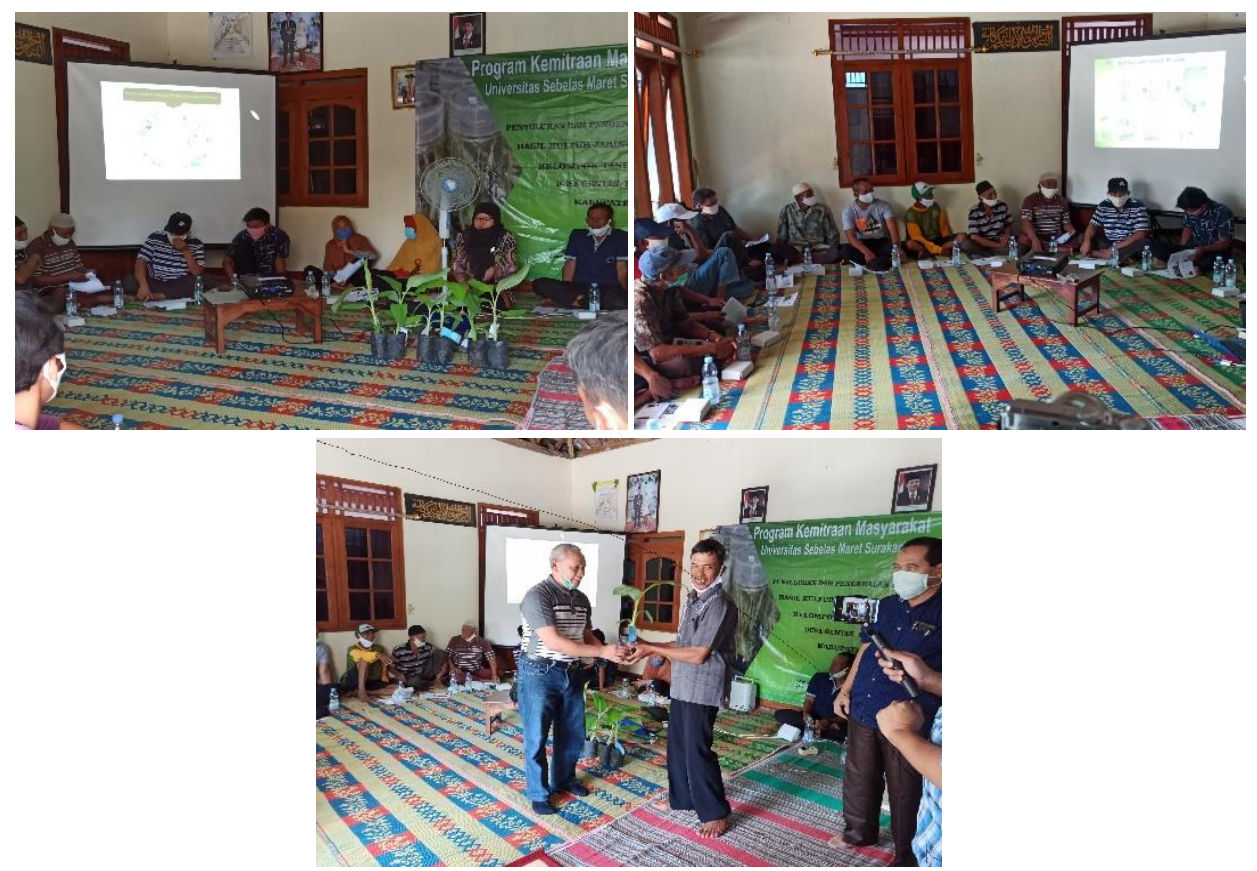

Gambar 1. Penyuluhan budidaya pisang menggunakan benih hasil kultur jaringan 
Kultur jaringan merupakan teknik pemisahan bagian tanaman baik jaringan, organ, ataupun embrio yang dikulturkan pada medium steril sehingga dapat beregenerasi dan berdiferensiasi menjadi tanaman lengkap (Zulkarnain, 2009). Prinsip dasar kultur jaringan adalah kemampuan suatu sel untuk beregenerasi menjadi tanaman utuh atau yang dikenal dengan teori totipotensi sel, (Iliev et al., 2010). Kultivar pisang cukup beragam antara lain pisang raja, pisang ambon, pisang kepok, pisang cavendish, pisang mas, pisang kluthuk, pisang barangan, dan lain-lain. Beberapa kultivar pisang yang disebutkan tadi merupakan kultivar pisang yang banyak diminati oleh masyarakat, sehingga pisang-pisang tersebut dilakukan perbanyakan secara kultur jaringan di Kebun Benih Hortikultura di Salaman, Magelang, Jawa Tengah serta di Kebun Plasma Nutfah Pisang di Giwangan, Umbulharjo, Yogyakarta.

Perbanyakan secara kultur jaringan memiliki beberapa keuntungan, antara lain sifat benih yang dihasilkan sama dengan induknya, bebas hama dan penyakit, jumlah benih yang dihasilkan banyak, serta pengangkutan lebih mudah dan murah (Meynarti, 2010; Yusnita et al., 2015). Penggunaan teknologi perbanyakan tanaman secara kultur jaringan memungkinkan untuk menghasilkan benih sepanjang tahun atau tidak mengenal musim, tidak membutuhkan tempat yang luas, dan benih yang dihasilkan bersifat true-to-type (Windiastika, 2013; Yusnita, 2004; Jha et al., 2011). Data sifat genetik dan ketersediaan bank plasma nutfah sangat dibutuhkan dalam teknologi kultur jaringan atau rekayasa genetik untuk menjamin keberadaannya (Jumari et al., 2002).

Setelah kegiatan penyuluhan selesai, setiap peserta diberikan benih pisang hasil perbanyakan secara kultur jaringan. Masingmasing peserta diberikan benih pisang sebanyak 5 tanaman, yang terdiri atas pisang rajabulu dan pisang barangan. Kedua kultivar pisang tersebut sudah banyak dikenal masyarakat, rasanya enak, mudah dibudidayakan, dan harganya cukup tinggi. Benih tanaman pisang yang diberikan diharapkan dapat ditanam oleh peserta di lahan yang dimiliki, baik di pekarangan maupun tegalan

\section{Praktik Penanaman}

Setelah pembagian benih tanaman pisang ke setiap peserta kegiatan pengabdian masyarakat, kegiatan dilanjutkan dengan praktik langsung budidaya tanaman pisang dengan benih yang dihasilkan secara kultur jaringan. Praktik ini dilakukan di tiga lahan pekarangan yang sudah ditentukan pada saat kunjungan dan observasi lapangan sebelumnya. Persiapan lubang tanam dan pemberian pupuk kandang sudah dilakukan sebelumnya. Pemberian pupuk kandang merupakan upaya untuk menambah nutrisi bagi tanaman. Pupuk kandang mengandung semua hara yang dibutuhkan tanaman baik hara makro (nitrogen, phosphor, kalsium, magnesium) maupun hara mikro, termasuk mangan. Disamping itu, pemberian pupuk kandang akan membantu memelihara keseimbangan hara dalam tanah (Andayani \& Sarido, 2013; Minardi \& Suryono, 2018). Pada saat kegiatan, praktik yang dilakukan langsung pada tahap penanaman benih, pemupukan awal, pengairan, dan pemberian paranet (Gambar 2). Budidaya pisang yang dikenalkan pada masyarakat berpedoman pada budidaya yang diterbitkan Pusat Kajian Hortikultura Tropika (Suhartanto et al., 2012). Jumlah tanaman pisang yang ditanam di setiap lahan demplot jumlahnya berbeda-beda tergantung pada luas lahan yang tersedia.

Selain dilakukan praktik bersama di lahan demplot, petani anggota Gapoktan masingmasing diberikan benih pisang hasil kultur jaringan sebanyak lima tanaman untuk ditanam di pekarangan masing-masing. Beberapa petani tertarik untuk menanam benih pisang tersebut di tegalan atau di sawah yang mereka miliki.

Melalui penanaman serta pemeliharaan pisang di lahan percontohan/demplot diharapkan dapat memberikan contoh praktik budidaya pisang yang baik sehingga hasil pisang yang diperoleh akan meningkat baik secara kuantitas maupun kualitasnya. Selain itu, dengan adanya kegiatan pengabdian masyarakat ini maka masyarakat akan mendapatkan tambahan ilmu, wawasan, dan pengetahuan mengenai budidaya pisang. Kegiatan ini juga dapat meningkatkan kemampuan masyarakat Desa Gentan untuk mengelola dan memanfaatkan lahan pekarangan untuk budidaya pisang serta menambah pendapatan.

\section{Monitoring dan Evaluasi}

Monitoring dan evaluasi terhadap kegiatan ini dilakukan secara berkala untuk membina dan mendampingi mitra sampai berhasil melakukan praktik penerapan teknologi budidaya tanaman pisang dengan menggunakan benih hasil kultur jaringan. Monitoring dan evaluasi serta pendampingan dilakukan melalui kunjungan 
langsung ke lapangan. Disamping itu, untuk memberikan pelayanan yang lebih cepat, setiap anggota Gapoktan dapat berkonsultasi tentang budidaya pisang tersebut secara online kepada Tim Pelaksana Pengabdian.
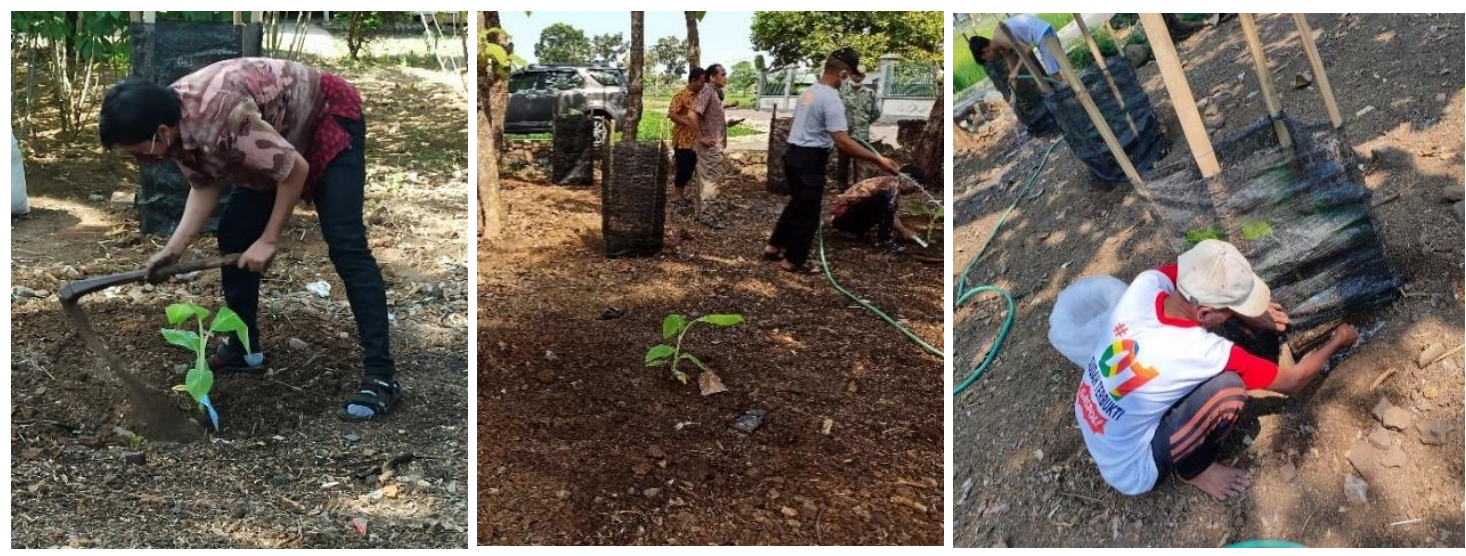

Gambar 2. Praktik penanaman pisang di lahan pekarangan

\section{KESIMPULAN}

Dalam pelaksanaan kegiatan program kemitraan masyarakat mengenai penyuluhan dan pengenalan budidaya pisang hasil kultur jaringan ini dapat diambil kesimpulan bahwa melalui kegiatan sosialisasi dan penyuluhan, anggota Gapoktan Sari Tani Desa Gentan memahami pemanfaatan pekarangan dengan budidaya pisang menggunakan benih yang berkualitas yaitu benih pisang hasil kultur jaringan. Selain itu, anggota Gapoktan Sari Tani mampu mempraktikkan budidaya pisang dengan menggunakan benih hasil kultur jaringan. Anggota Gapoktan Sari Tani juga memberikan tanggapan yang sangat baik dengan berpartisipasi dan mengikuti kegiatan secara penuh, serta dapat melakukan praktik penanaman pisang dengan benih hasil kultur jaringan di pekarangannya. Berdasarkan pelaksanaan pengabdian yang sudah terlaksana, kegiatan ini dapat memberikan kontribusi nyata terhadap optimalisasi pemanfaatan lahan pekarangan masyarakat di Desa Gentan, Kecamatan Bendosari, Kabupaten Sukoharjo.

\section{UCAPAN TERIMA KASIH}

Ucapan terimakasih disampaikan kepada Lembaga Penelitian dan Pengabdian kepada Masyarakat (LPPM) Universitas Sebelas Maret (UNS) yang telah mendanai kegiatan pengabdian ini melalui Skema Program Kemitraan Masyarakat (PKM) dengan sumber dana PNBP UNS Tahun Anggaran 2020.

\section{DAFTAR PUSTAKA}

Ambarita, M. D. Y., Bayu, E. S., \& Setiado, H. (2016). Identifikasi karakter morfologis pisang (Musa Spp.) di Kabupaten Deli Serdang. Jurnal Agroekoteknologi Universitas Sumatera Utara, 4(1), 19111924.

https://doi.org/10.32734/jaet.v4i1.12404

Andayani, \& Sarido, L. (2013). Uji empat jenis pupuk kandang terhadap pertumbuhan dan hasil tanaman cabai keriting (Capsicum annum L.). Jurnal AGRIFOR, XII(1), 22-29.

Arifin, H. S., Sakamoto, K., \& Chiba, K. (1996). Effects of the fragmentation and the change of the social and economical aspects on the vegetation structure in the rural home gardens of West Java, Indonesia. Journal of the Japanese Institute of Landscape Architecture, 60(5), 489-494. https://doi.org/10.5632/jila.60.489

Iliev, I., Gajdošová, A., Libiaková, G., \& Jain, S. M. (2010). Plant micropropagation. In M. R. Davey and P. Anthony (Ed.), Plant Cell Culture: Essential Methods (pp. 1-23). John Wiley and Sons, Ltd. New Jersey,. https://doi.org/10.1002/9780470686522.ch 1

Jha, Z., Sharma, S. N., Sahu, H., \& Chandel, G. (2011). Generation of true to type micropropagated banana cultivar 'Grand Naine.' International Journal of Advanced Biotechnology Research, 1(1), 1-10. 
Jumari, Utami, S., \& Wiryani, E. (2002). Identifikasi plasma nutfah pisang di Semarang Jawa Tengah.

Meynarti, S. D. I. (2010). Produksi benih lada dengan teknik kultur jaringan. Balitri, Sukabumi.

Minardi, S., \& Suryono. (2018). Pengelolaan pupuk kandang sapi dalam rangka meningkatkan mutu di Desa Jetis, Kecamatann Sambirejo, Kabupaten Sragen. Jurnal of Community Empowering a Services, 2(2), 30-33.

Nahraeni, W., \& Rahayu, A. (2015). Optimalisasi pemanfaatan pekarangan di Desa Babakan, Kecamatan Cisaat, Kabupaten Sukabumi. Media Pengabdian Kepada Masyarakat Qardhul Hasan, 1(1), 42-48.

Sayuti, M., Puspasari, C., Anshar, K., \& Zeki, M. (2019). Potensial use of backyard for oyster mushroom (Pleurotus ostreatus) cultivation to increase family income; studies on break-event point analysis. IOP Conference Series: Materials Science and Engineering, $536(1)$ https://doi.org/10.1088/1757$899 X / 536 / 1 / 012132$

Suhartanto, M. R., Sobir, \& Harti, H. (2012).
Teknologi sehat budidaya pisang: dari benih sampai pasca panen. Pusat Kajian Hortikultura Tropika, LPPM IPB.

Suseno, N. (2017). Micropropagation of banana plant (Musa paradisiaca) cv . raja bulu through tissue culture for diversification of food and feed. The 7th International Seminar on Tropical Animal Production Contribution of Livestock Production on Food Sovereignty in Tropical Countries, 795-798.

Windiastika, G. (2013). Peranan kultur jaringan dalam memperoleh benih unggul. Balai Besar Perbenihan dan Proteksi Tanaman Perkebunan Surabaya.

Yusnita. (2004). Kultur jaringan, cara memperbanyak tanaman secara efisien. In Agromedia Pustaka.

Yusnita, Danial, E., \& Hapsoro, D. (2015). In vitro shoot regeneration of Indonesian bananas (Musa spp.) cv. Ambon Kuning and Raja Bulu, plantlet acclimatizationand field performance. Agrivita, 37(1), 51-58. https://doi.org/10.17503/agrivita-2015-37$1-\mathrm{p} 051-058$

Zulkarnain. (2009). Kultur jaringan tanaman. Bumi Aksara. 